\title{
Preventive home visits to elderly people by community nurses in The Netherlands
}

\author{
Ada Kerkstra PhD \\ Co-ordinator Communtty Nursing Research, Netherlands Institute of Primary Health Care, \\ Utrecht
}

Elsbeth Castelein MNSc

Department of Nursing Science

and Hans Philipsen PhD

Professor of Medical Sociology, Department of Nursing Science, Universtty of Limburg,

Maastricht, The Netherlands

KERKSTRA A, CASTELEIN E \& PHILIPSEN H (1991) Journal of Advanced Nursing 16, 631-637

Preventive home visits to elderly people by community nurses in The Netherlands

This study aims at a description of the current position of preventive home visits to the elderly by community nurses in The Netherlands Over a penod of 8 weeks, a representative sample of 108 community nurses and 49 community nursing auxiliaries at 47 different locations paid a total number of 215 preventive home visits to elderly people Clients' characteristics, the nature of care delivered by the nurse, and the length of the home visit were recorded for each home visit The results suggested that community nurses and nursing auxiliaries spent very little time on preventive home visits During the home visits, both types of nurses tried to increase the self-care agency of the elderly by giving education or advice Furthermore, community nurses often paid more attention to the assessment and examination of existing or emerging self-care deficits of the elderly people visited than nursing auxiliaries In spite of the fact that the importance of preventive care for the elderly is recognized, resources are scarce It is therefore recommended that more research be carried out on the cost effectiveness of preventive home visits

\section{INTRODUCTION}

In The Netherlands, as is the case in other countnes (Baker et al 1987, Edwards 1988, Evashwick et al 1984, Siem 1986, Speakman 1984), elderly people are an important group of consumers of health care services Due to a nse in life expectancy and technological developments in health care, there is an increasing proportion of the population in

Correspondence Dr A Kerkstra NIVEL (Netherlands Institute of Promary Health Care), PO Bax 1568, 3500 BN Ltrecht, The Netherlands the 65 and over age group While in 1960 only $87 \%$ of the Dutch population was aged 65 or over, in 1989 approximately $127 \%$ of the population fell into this category Current projections indicate that by the year 2000 approximately $14 \%$ will be classified as 'elderly' (Centraal Bureau voor de Statistiek 1990) Consequently, the steady rise in the number of elderly people is an important deciding factor in health care policy Recent White Papers (Minustene van Welzinn, Volksgezondheid en Cultuur 1989a, b) aum at a coherent policy regarding preventive health care for the 
elderly In those policy documents it is emphasized that feelings of independence and responsibility are important aspects in the quality of life of elderly people In addition, there has been a growing emphasis on the care of elderly people in the community, in particular on the surveillance of such groups to detect early symptoms of disease

The main groups of professionals concerned with the surveillance of elderly people are community nurses and community nursing auxilianes In England, a distinction is made between district nurses and health visitors (Dunnell \& Dobbs 1982, Baker et al 1987) In The Netherlands, these roles are combined, i e community nurses are generalists One of their tasks is to conduct preventive home visits to the elderly Community nurses visit these elderly without being referred to them or called by them This is important when treating elderly people, for they often report symptoms late, attributing them to the normal changes that occur with age (Vetter et al 1984) The aim of these visits is promotion of health and prevention of lliness This has to be achieved by early detection of symptoms, giving education, advice and support (Hoornstra \& Van Druenen 1985, Nationale Kruisvereniging 1981, 1987)

However, little is known about how many community nurses and nursing auxilianes in The Netherlands actively conduct preventive home visits to the elderly, how much time they spend on this task, what kand of elderly people are visited and what sort of activities are undertaken during these visits The present study will endeavour to assess the state of the art in preventive home visits to the elderly by community nurses in The Netherlands

\section{Theoretical framework and research questions}

In the present study, Orem's Self-Care Deficit Theory (Orem 1985) was used as a conceptual framework for preventive home visits to elderly people The community nurse or nursing auxiliary conducts a home visit to determine whether there are any self-care deficits, either now or for the future The term 'self-care deficit' refers to the relationship between self-care agency and therapeutic selfcare demands of individuals in which capabilities for selfcare are not equal to meeting some or all of the components of their therapeutic self-care demands, because of existing limitation (Orem 1985)

The first (diagnostic) phase of the nursing process is to determine if there is existing or emerging self-care deficit In this phase, the community nurse has to make observations to answer, among others, the following initial questions

1 What is the patient's therapeutic self-care demand? Now? At a future time?
2 Is there a self-care deficit for the therapeutic self-care demand?

3 If so, what is its nature and the reasons for its existence?

Orem defines this first phase of the nursing process as The initial and continuing determination of why a person should be under nursing care' (Orem 1985)

In Orem's theory, three basic vanations in nursing systems are recognized (a) wholly compensatory nursing systems, (b) partly compensatory nursing systems, and (c) supportive-educative (developmental) nursing systems (Orem 1985) Because the community nurse visits the elderly without being referred to them or called by them, it is most likely she will use the supportive-educative nursing system Through education and advice she tries to increase the self-care agency of the individual elderly person in order to prevent a self-care deficit or, in case of an already exısting self-care deficit, to make it disappear For instance, when no existing or emerging self-care deficit has been observed, the community nurse can give some information about the community nursing services and the accessibility of the services in case the older person needs help in the future The community nurse or nursing auxilyary contributes in this way to the health development and general well-being of the elderly person

Consistent with its aims and theoretical framework, this study has attempted to find answers to the following questions

1 What percentage of the community nurses and community nursing auxilianes in The Netherlands actively conduct preventive home visits to elderly people?

2 How many working hours are spent on these visits?

3 What are the individual characteristics of the elderly (age, sex, living situation) visited by the community nurses and nursing auxilianes?

4 What occurs during a preventive home visit? What is the ratio between observing self-care deficits and the activities to increase the self-care agency? Are there any differences between home visits conducted by community nurses and those conducted by nursing auxilianes?

\section{METHOD}

A representative national sample of 108 community nurses and 49 community nursing auxiliaries at 47 different locations in The Netherlands was studied Durng a penod of 8 weeks, they recorded all preventive home visits pard to the elderly and the activities undertaken durng these visits They also kept records of the tume spent on these home visits All the communty nurses and auxilianes worked 
Table 1 Percentage of community nurses and nursing auxilianes who conduct preventive home visits to the elderly, the average number of home visits per type of nurse and the average number of home visits per type of nurse actively conducting home visits (8-week period)

\begin{tabular}{llll}
\hline & $\begin{array}{l}\text { Percentage } \\
\text { of nurses } \\
\text { conducting } \\
\text { preventive } \\
\text { home visits }\end{array}$ & $\begin{array}{l}\text { Mean number } \\
\text { of preventive } \\
\text { home visits } \\
\text { of the } \\
\text { total groups }\end{array}$ & $\begin{array}{l}\text { Mean number of } \\
\text { preventive home } \\
\text { visits of the nurses } \\
\text { actively conducting } \\
\text { those visits }\end{array}$ \\
\hline $\begin{array}{l}\text { Community nurses }(n=108) \\
\begin{array}{l}\text { Community nursing auxiliaries } \\
\text { Total group }(n=157)\end{array}\end{array}$ & 26 & 09 & 35 \\
\hline $\begin{array}{l}\text { Total } \\
\text { The }\end{array}$ & 31 & 26 & 60 \\
\hline
\end{tabular}

during office hours They recorded their activities on a diary sheet which has been developed and tested for reliability and valıdity in a pilot study (Kerkstra \& de Wit 1988) For each home visit the patients' name, sex, age and living situation was recorded The following nursing activities were distinguished based on Orem's Self-Care Deficit Theory

1 Assessment of existing or emerging self-care deficits through observation and examination of physical symptoms, mental problems, social problems, material problems

2 Increasing the self-care agency of the elderly person through education or advice about food/diet, medicines, hygienic self-care, heating the home, safety in and around the home, community nursing services, auxiliary (emergency) services, tasks of other health and social services, old people's home/sheltered accommodation, rights of the elderly, other topics, encouraging activity on the part of the elderly, referral to other health care providers, e $g$ the general practitioner, administration, recording information on the elderly's record card, social talk, other activities

\section{RESULTS}

\section{Percentage of community nurses and nursing} auxiliaries who conduct preventive home visits to the elderly

Table 1 shows that only $31 \%$ of the 157 community nurses and community nursing auxilianes have been visiting at least one elderly person over 8 weeks More community nursing auxilianes ( $43 \%$ ) conducted preventive home visits than community nurses $(26 \%)\left(\chi^{2}=45, P=003\right)$ Furthermore, there was a difference in the number of preventive home visits conducted by community nurses and community nursing auxiharies $(t=-242, P=002)$ Within the total group of auxilianes, an average number of 26 home visits (with a range of 0 to 17 home visits) was conducted over 8 weeks whereas, for the total group of community nurses, the mean number of home visits was 09 per community nurse (range 0 to 13 home visits) For the auxiliaries who actively conducted preventive home visits $(43 \%)$, the average number of home visits was 6 , and for the community nurses who actively conducted preventive home visits $(26 \%) 35$

\section{Tume spent on preventive home visits to the elderly}

The average length of all preventive home visits was $\mathbf{5 0}$ minutes with a range of 13 minutes to 2 hours and 5 minutes The mean duration of a visit conducted by a community nurse was 45 munutes, whereas the mean duration of a visit conducted by an auxiliary was 54 minutes This difference in length of preventive home visits conducted by the different types of nurses appeared to be significant $(t=333$, $P=0$ 001)

The average time spent on preventive home visits to the elderly by an average community nurse was 21 minutes a month, and by an average community nursing auxiliary 64 minutes a month (time spent on travel excluded) These results mean that nursing auxilianes spent only $1 \%$ of their working hours on preventive home visits to the elderly, and community nurses even less

\section{Individual characteristics of elderly people receiving a preventive home visit}

The elderly receiving a preventive home visit were predominantly women (70\%) and approxumately $65 \%$ of the elderly were at least 75 years old The average age of all visited elderly was 77 Table 2 shows that more than half of the preventive home visits $(57 \%)$ were to elderly people 
Table 2 Percentage distribution of preventive home visits $(n=215)$ by type of nurse and domestic status of the elderly people visited
Domestic status of the elderly people visited

$\begin{array}{llll}\begin{array}{l}\text { Living } \\ \text { alone }\end{array} & \begin{array}{l}\text { Living with } \\ \text { spouse }\end{array} & \begin{array}{l}\text { Living with } \\ \text { children }\end{array} & \text { Total }\end{array}$

\begin{tabular}{lrrrl}
\hline Community nurses & 69 & 24 & 7 & $100(n=99)$ \\
Nursing auxiliaries & 47 & 43 & 10 & $100(n=116)$ \\
Total & 57 & 35 & 8 & $100(n=215)$ \\
\hline
\end{tabular}

living alone In addition, community nurses more often made home visits to the elderly living alone than community nursing auxilianes did $\left(\chi^{2}=105, P=0005\right)$ Those of the elderly living alone were predominantly women (82\%) This is in keeping with the Dutch population statistics which show that $80 \%$ of those 75 years and above still living alone are females (Centraal Bureau voor de Statıstrek 1990)

Nature of community nursing care delivered during the preventive home visits

Table 3 gives an overview of the activities undertaken by community nurses and community nursing auxilianes during the preventive home visits The results show that community nurses pard more often attention to the assessment of existing or emerging self-care deficats of the elderly people visited compared with community nursing auxiliaries In particular, they focused more attention on possible self-care deficits in the mental and social functioning of the elderly Community nurses pard attention to the assessment of potential self-care deficits in $87 \%$ of all visits, whereas this activity was carried out by nursing auxilanes only in $68 \%$ of visits This difference appeared to be significant $\left(\chi^{2}=95, P=0.002\right)$

Both community nurses and nursing auxilianes tried to increase the self-care agency of the elderly people visited by giving education or advice on many different topics Two topics were given emphasis by community nurses more often than by nursing auxulianes These were information on the food or diet of the elderly person, and about old people's home or sheltered accommodation. Furthermore, the community nurses more often encourage those visited to undertake some activity Additional analyses showed that the above-mentioned differences between the activities undertaken by community nurses and nursing auxulianes were not explained by the fact that community nurses made more home visits to elderly people living alone
In summary, in more than $90 \%$ of all preventive home visits, community nurses as well as nursing auxilianes carned out activities to increase the self-care agency of the elderly visited In about $10 \%$ of the cases, both types of nurses referred the elder person to another care provider In most cases this was the general practitioner

\section{DISCUSSION}

It can be concluded from this study that community nurses and nursing auxilianes in The Netherlands spend little time on conducting preventive home visits to the elderly In this study, nursing auxilianes spent only $1 \%$ of their working hours on these visits, and community nurses even less

\section{Preventive home visits}

The finding that more nursing auxilianes (43\%) than community nurses $(26 \%)$ conduct preventive home visits to the elderly is possibly due to the fact that community nurses have less time available for these visits, because community nurses, in contrast to nursing auxilianes, also deliver preventive care to mothers and their young children (up to the age of 4 years) (Kerkstra 1989)

As was mentioned in the introduction to this paper, policy makers recognize the importance of preventive health care for the elderly In addition, some studies performed in Wales (e g Vetter et al 1984) and in Denmark (e $\mathrm{g}$ Hendriksen et al 1984) showed beneficial effects of preventive home visits Preventive care is concerned with maintaining the health of the elderly Preventive home visits to elderly people by community nurses and nursing auxihanes contribute to maintenance of good health of the elderly by increasing the self-care agency of the elderly before a self-care deficit emerges If an existang or emerging self-care deficat has been observed, the community nurse (or nursing auxihary) can try to increase the self-care agency of the elderly through education and advice in 
Table 3 Percentage

distribution of categories of

care delivered by community

nurses and community

nursing auxilianes duning

preventive home visits to the elderly
The difference between community nurses and nursing auxilianes is stgnificant $(P<0.03)$
Community nurses

(99 home visits)
Nursing auxilianes

(116 home visits)
Assessment of existent or emerging self-care deficits through observation and examination of

$\begin{array}{cc}61 & 48 \\ 63 & 37^{*} \\ 44 & 29^{*} \\ 11 & 4\end{array}$

Increasing self-care agency of the elderly through education or advice about

$\begin{array}{lrr}\text { food/diet } & 64 & 49^{*} \\ \text { medicines } & 58 & 45 \\ \text { hygienic self-care } & 59 & 61 \\ \text { heating the home } & 6 & 1 \\ \text { safety in and around the home } & 35 & 32 \\ \text { community nursing services } & 33 & 41 \\ \text { auxiliary (emergency) services } & 32 & 36 \\ \text { tasks of other health and social services } & 24 & 18 \\ \text { old people's home/sheltered } & & \\ \text { accommodation } & 25 & 13^{*} \\ \text { nights of the elderly } & 4 & 5 \\ \text { other topics } & 26 & 24\end{array}$

Encourage the elderly person to undertake some activities

Referral to other care providers

$\begin{array}{rr}43 & 26^{*} \\ 9 & 10 \\ 20 & 18 \\ 54 & 47 \\ 24 & 17\end{array}$

order to prevent the self-care deficit or to make it disappear In spite of recognition of the importance of these home visits, little tume is spent on this task by community nurses and nursing auxilanes

A recent study (Vorst-Thussen et al 1990), in which a representative national sample of 400 community nurses and nursing auxilianes filled in a questionnarre, showed that $34 \%$ of the community nurses and $40 \%$ of the nursing auxiliaries would like to spend more time on health promotion and prevention Recently, the National Cross Association (the Dutch organization for community nursing services) also reported that the number of preventive home visits conducted by community nurses and nursing auxilianes has been decreasing during the last few years in favour of delivering nursing care to the sick at home (Nationale Krusvereniging 1990)

The decrease in the number of preventive home visits was explained as follows First, over the last few years the budget of the National Cross Association has been reduced, whereas in the early 1980 s the budget was allowed to grow by $4 \%$ each year Second, over the last 10 years there has been a shift in government policy from specialist and residential care towards home care and primary health care Patients are discharged from hospital earlier and people are kept at home (in the community) for as long as possible As a consequence, more people need technical nursing care and assistance with activities of dauly living (ADL) at home, and consequently, the workload and the caseload of community nurses has increased (Nationale Krusvereniging 1990)

Some studies carned out in England (Dunnell \& Dobbs 1982, Wade et al 1983) showed simular fundings Health visitors, nurses who are concerned with the promotion of health and the prevention of 1 ll health, spend only $9 \%$ of their working hours with those aged 65 or more and approximately $62 \%$ with chuldren (Dunnell \& Dobbs 1982) Wade 
et al (1983) reported that only $4 \%$ of the health visitor's time was spent on direct contact with old people

Because distnct nurses spend most of their time with old people, Ross (1987) asked whether it is justifiable and cost effective, when resources are scarce, to have two nurses for the elderly - a sick person's nurse and a 'well person's nurse? F Furthermore, according to Fatchett (1990) the role of health visitors in England is threatened by recent policy documents For instance, in the White Paper 'Promoting Better Health' (HMSO 1987) a key role is given to family doctors in the promotion of health, instead of to health visitors Fatchett argues that health visitors should strengthen their role not only by examination of the content of their work but also by examination of the rapidly changing context of primary health care provision

\section{Self-care deficits}

During nearly all preventive home visits, both community nurses and nursing auxalianes tned to develop the self-care agency of the elderly people visited by giving instruction or advice about many different topics, for instance about food or diet, hygienic self-care and medicines However, the results showed that community nurses more often pard attention to the assessment of existing or emerging selfcare deficits of the elderly people visited than community nursing auxilianes This result is in keeping with the job descriptions of community nurses and nursing auxilianes Nursing auxilianes (second-level nurses) are not trained to assess and examine hugh-risk groups (Nationale Raad voor de Volksgezondheid 1988) Accordingly, to assure the quality of the home visits, extra training for nursing auxilianes is needed for this important task

\section{CONCLUSION}

Both policy-makers, as well as community nurses and nursing auxilianes in The Netherlands, recognize the importance of preventive health care for the elderly In addition, some studies in Wales and Denmark showed positive effects of preventive home visits to elderly people At this time in The Netherlands a simular experiment is being carned out (van Rossum \& Fredenks 1988) However, due to an increasing workload, communty nurses and nursing auxalianes spend little time on this task.

Because resources are scarce, it is recommended that further research is carned out on the cost effectiveness of preventive home visits In particular, more insight is needed to determine which activities during these home visits are the most beneficial and to whom

\section{References}

Baker G , Bevan J M , McDonnell L \& Wall B (1987) Communtty Nursing Research and Recent Developments Croom Helm, London.

Centraal Bureau voor de Statistiek (1990) Statishsch Zakboek 1990 SDU Uitgevery, 's-Gravenhage, The Netherlands

Dunnell K \& Dobbs I (1982) Nurses Workang in the Community HMSO, London

Edwards N (1988) Nursing in the Community A Team Approach for Wales Report of the Review of Community Nursing in Wales

Evashwick C, Rowe G, Diehr P \& Branch L (1984) Factors explaining the use of health care services by the elderly Health Services Research 19(3), 358-382

Fatchett A B (1990) Health visiting a withering profession? Joumal of Adoanced Nursing 15, 216-222

HMSO (1987) Promoting Better Health Her Majesty's Stationery Office, London

Hendriksen C. Lund E \& Stromgard E (1984) Consequences of assessment and intervention among elderly people a three year randomised controlled trial Britsh Medical Journal 289, 1522-1524

Hoornstra R \& Van Druenen H (1985) Preventieve husbezoeken aan ouderen een geschikt instrument voor het juiste doel Maatschappelijke Gezondherdszorg 13(9), 24-28

Kerkstra A (1989) Community nursing in The Netherlands In Community Nursing Proceedings of the International Conference on Community Nursing, 16-17 March 1989, 's-Hertogenbosch, The Netherlands (Kerkstra A \& Verhelj R eds), NIVEL, Utrecht

Kerkstra A \& De Wit AMGJ (1988) Het werk van de wijkverpleging gemeten instrumentontwikkeling Verpleegkunde 3, 140-152

Minustene van Welzujn, Volksgezondheid en Cultuur (1989a) Ontwerpkemdocument Gezondhetdsbelend voor de Jaren 19901995 Doelgencht Veranderen Ministene van Welzun, Volksgezondheid en Cultuur, Rujswijk. The Netherlands

Minustene van Welzyjn, Volksgezondheid en Cultuur (1989b) Veroudering en Preventie Minustene van Welzıjn, Volksgezondheid en Cultuur, Russwijk, The Netherlands

Nationale Kruisvereniging (1981) Preventiepe Bejaardenzorg in de Wijkoerpleging Nationale Krusvereniging, Bunnik, The Netherlands

Nationale Krusvereniging (1987) Preventieve Ouderenzorg door het Kruiswerk Nationale Kruivereniging, Bunnik, The Netherlands

Nationale Krusvereniging (1990) Krutswerk voor Zorg en Voorzorg Nationale Kruisvereniging, Bunnik, The Netherlands

Nationale Raad voor de Volksgezondheid (1988) Verpleegkundrg Beroepsprofiel Nationale Raad voor de Volksgezondheid, Zoetermeer, The Netherlands

Orem DE (1985) Nursing Concepts of Practice McGraw Hill, New York. 
Ross F (1987) Distnct Nursing Recent Adoances in Nursing 15, $132-160$

Siem H (1986) Choices for Health An Introduction to the Health Services in Norway Universitetsforlaget, Oslo

Speakman J (1984) Measurng the immeasurable Nursing Times $80(22), 56-58$

van Rossum HJL \& Frederiks CMA (1988) Heeft preventief ouderenbezoek door wijkverpleegkundigen zin? Tijdschrift voor Gerontologie en Gernatrie 19, 3-7
Vetter N I, Jones D A. \& Victor CR. (1984) Effect of health visitors working with elderly patients in general practice a randomised controlled tral British Medical Joumal 288, 369-372

Vorst-Thyssen T , Van den Brnkk-Munen A. \& Kerkstra A. (1990) Het Werk van Wijkoerpleegkundigen en Wijkziekenverzorgenden in Nederland NIVEL, Utrecht

Wade B, Sawyer L \& Bell J (1983) Dependency with Dignity Bedford Square Press, London 
This document is a scanned copy of a printed document. No warranty is given about the accuracy of the copy. Users should refer to the original published version of the material. 